\section{ENVIRONMENTAL} MANAGEMENT \&

\section{ENRICHMENT \\ FACIIITIES}

\title{
Postremediation Monitoring Program Baseline Assessment Report, Lower East Fork Poplar Creek, Oak Ridge Y-12 Plant, Oak Ridge, Tennessee
}

\author{
PECEIVED \\ APR 201998 \\ OSTI
}

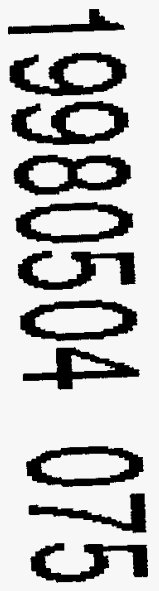

This document has been approved by the Y-12 Plant Technical Information Office for release to the public. Date: $04 / 06 / 98$

\section{DISCLAIMER}

\begin{abstract}
This report was prepared as an account of work sponsored by an agency of the United States Government. Neither the United States Government nor any agency thereof, nor any of their employees, makes any warranty, express or implied, or assumes any legal liability or responsibility for the accuracy, completeness, or usefulness of any information, apparatus, product, or process disclosed, or represents that its use would not infringe privately owned rights. Reference herein to any specific commercial product, process, or service by trade name, trademark, manufacturer, or otherwise does not necessarily constitute or imply its endorsement, recommendation, or favoring by the United States Government or any agency thereof. The views and opinions of authors expressed herein do not necessarily state or reflect those of the United States Government or any agency thereof.
\end{abstract}

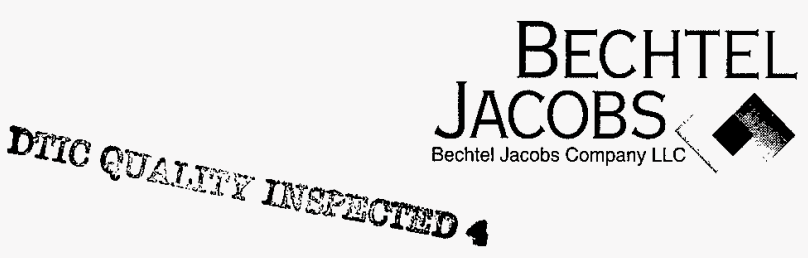




\title{
Postremediation Monitoring Program \\ Baseline Assessment Report, Lower East Fork Poplar Creek, Oak Ridge Y-12 Plant, Oak Ridge, Tennessee
}

\author{
M. S. Greeley, Jr. \\ T. L. Ashwood \\ L. A. Kszos \\ M. J. Peterson \\ T. L. Phipps \\ C. D. Rash \\ G. R. Southworth
}

Date Issued-April 1998

Prepared for the

U.S. Department of Energy

Office of Environmental Management

Environmental Management Activities at the

OAK RIDGE Y-12 PLANT

Oak Ridge, Tennessee 37831 managed by

BECHTEL JACOBS COMPANY LLC

for the

U.S. DEPARTMENT OF ENERGY

under contract DE-AC05-98OR22700

DASTTIBUTON OF TMS DOCUMENT IS UNLIMTTED

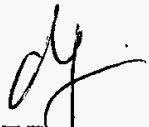




\section{Author Affiliations}

M. S. Greeley, Jr., T. L. Ashwood, L. A. Kszos, M. J. Peterson, C. D. Rash, and G. R. Southworth work for Lockheed Martin Energy Research Corporation in Oak Ridge National Laboratory's Environmental Sciences Division. T. L. Phipps works for CKY, Inc. 


\section{ACKNOWLEDGMENTS}

The authors, M. S. Greeley, Jr., T. L. Ashwood, L. A. Kszos, M. J. Peterson, T. L. Phipps, C. D. Rash, and G. R. Southworth, wish to thank the staff of the Oak Ridge National Laboratory Environmental Sciences Division (ESD) toxicology laboratory, including Belinda Konetsky, Gail Morris, Kitty McCracken, and Ramie Wilkerson, for providing outstanding technical support. Sincere thanks go to Dave Farmer, Roxanna Hinzman, and Mac Stubbs of ESD for their skillful support for field activities and to Della Marshall of ESD for assistance with quality assurance/quality control documentation. Tina Bennett is gratefully acknowledged for her outstanding support with the financial aspects of this project.

Sincere appreciation goes to Roxanna Hinzman for her involvement in the planning and early supervision of this assessment project. Sig Christensen, Kathe Fischer, Craig Brandt, and Tammy Beaty provided excellent support in the management of project data. Additional thanks go to Sig Christensen and Tammy Beaty for their work in the generation of the site map used in this report.

We also acknowledge the continuing support and encouragement of Tom McLaughlin, Lockheed Martin Energy Systems, Inc., Lower East Fork Poplar Creek Remedial Action Program Manager, during the course of the baseline assessment and the writing of this document. 


\section{CONTENTS}

ACKNOWLEDGMENTS $\ldots \ldots \ldots \ldots \ldots \ldots \ldots \ldots \ldots \ldots \ldots \ldots \ldots \ldots \ldots \ldots \ldots$ iii

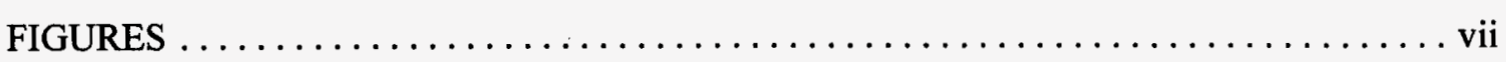

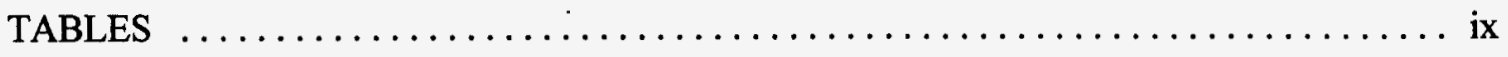

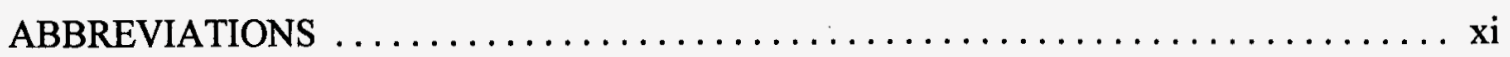

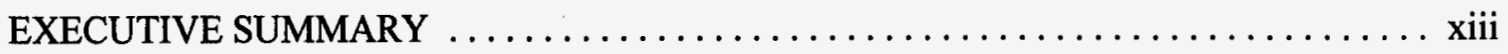

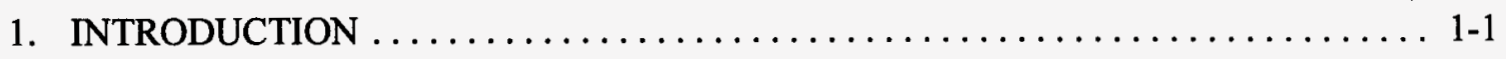

2. TOXICITY MONITORING $\ldots \ldots \ldots \ldots \ldots \ldots \ldots \ldots \ldots \ldots \ldots \ldots \ldots \ldots \ldots \ldots \ldots \ldots \ldots, 2-1$

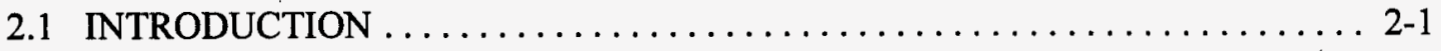

2.2 MATERIALS AND METHODS $\ldots \ldots \ldots \ldots \ldots \ldots \ldots \ldots \ldots \ldots \ldots \ldots \ldots \ldots, 2-1$

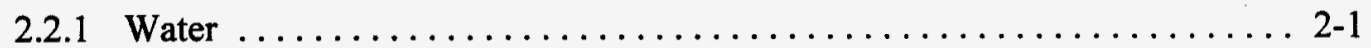

2.2.2 Sediment $\ldots \ldots \ldots \ldots \ldots \ldots \ldots \ldots \ldots \ldots \ldots \ldots \ldots \ldots \ldots \ldots \ldots \ldots, 2-2$

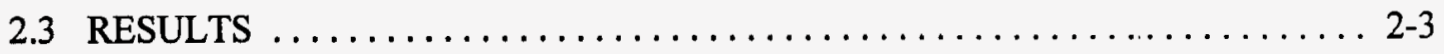

2.3.1 Water $\ldots \ldots \ldots \ldots \ldots \ldots \ldots \ldots \ldots \ldots \ldots \ldots \ldots \ldots \ldots \ldots \ldots \ldots \ldots \ldots \ldots \ldots \ldots \ldots, 3$

2.3.2 Sediment $\ldots \ldots \ldots \ldots \ldots \ldots \ldots \ldots \ldots \ldots \ldots \ldots \ldots \ldots \ldots \ldots \ldots \ldots \ldots \ldots \ldots \ldots \ldots \ldots, 2-5$

2.4 DISCUSSION $\ldots \ldots \ldots \ldots \ldots \ldots \ldots \ldots \ldots \ldots \ldots \ldots \ldots \ldots \ldots \ldots \ldots \ldots \ldots \ldots \ldots \ldots \ldots \ldots, 7$

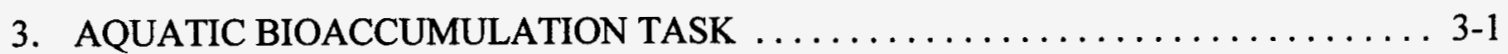

3.1 INTRODUCTION $\ldots \ldots \ldots \ldots \ldots \ldots \ldots \ldots \ldots \ldots \ldots \ldots \ldots \ldots \ldots \ldots \ldots \ldots \ldots \ldots \ldots \ldots \ldots \ldots, 1$

3.2 MATERIALS AND METHODS $\ldots \ldots \ldots \ldots \ldots \ldots \ldots \ldots \ldots \ldots \ldots \ldots, 3-1$

3.3 RESULTS $\ldots \ldots \ldots \ldots \ldots \ldots \ldots \ldots \ldots \ldots \ldots \ldots \ldots \ldots \ldots \ldots \ldots \ldots \ldots \ldots \ldots \ldots \ldots, 2$

3.4 DISCUSSION $\ldots \ldots \ldots \ldots \ldots \ldots \ldots \ldots \ldots \ldots \ldots \ldots \ldots \ldots \ldots \ldots \ldots \ldots \ldots \ldots \ldots \ldots \ldots, 2$

4. SOIL AND ASSOCIATED BIOTA $\ldots \ldots \ldots \ldots \ldots \ldots \ldots \ldots \ldots \ldots \ldots \ldots, 1$

4.1 INTRODUCTION $\ldots \ldots \ldots \ldots \ldots \ldots \ldots \ldots \ldots \ldots \ldots \ldots \ldots \ldots \ldots \ldots \ldots \ldots \ldots, 4,1$

4.2 MATERIALS AND METHODS $\ldots \ldots \ldots \ldots \ldots \ldots \ldots \ldots \ldots \ldots \ldots, 4,1$

4.3 RESULTS $\ldots \ldots \ldots \ldots \ldots \ldots \ldots \ldots \ldots \ldots \ldots \ldots \ldots, \ldots, \ldots \ldots \ldots \ldots, 2$

4.4 DISCUSSION $\ldots \ldots \ldots \ldots \ldots \ldots \ldots \ldots \ldots \ldots \ldots \ldots \ldots \ldots \ldots \ldots \ldots \ldots \ldots \ldots \ldots, 2$

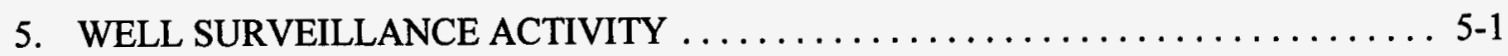

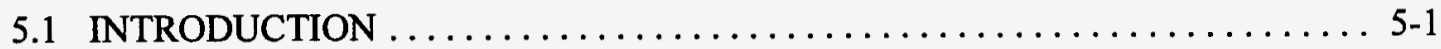

5.2 MATERIALS AND METHODS $\ldots \ldots \ldots \ldots \ldots \ldots \ldots \ldots \ldots \ldots \ldots \ldots \ldots \ldots \ldots \ldots \ldots \ldots, 1$

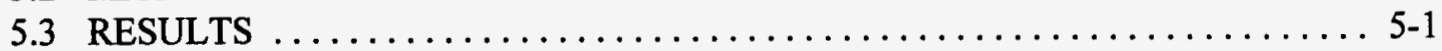

5.4 DISCUSSION $\ldots \ldots \ldots \ldots \ldots \ldots \ldots \ldots \ldots \ldots \ldots \ldots \ldots \ldots \ldots \ldots \ldots \ldots \ldots \ldots \ldots \ldots \ldots, 1$

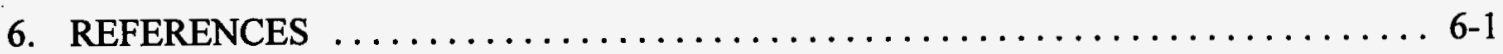




\section{FIGURES}

1.1 Map of sampling sites included in the baseline assessment for the Lower East Fork Poplar Creek Postremediation Monitoring Program . . . . . . . . 1-2

2.1 Total mercury (top) and methylmercury (bottom) in surface water from East Fork Poplar Creek and Hinds Creek

3.1 Mean concentration of total mercury in composite samples $(n=3)$ of forage fish (stonerollers, Campostoma anomalum, and striped shiners, Luxilus chryscephalus), from sites in EFPC and Hinds Creek, fall and winter 1995/1996

3.2 Mean concentration of methylmercury in composite samples $(n=3)$ of forage fish (stonerollers, Campostoma anomalum, and striped shiners, Luxilus chryscephalus), from sites in EFPC and Hinds Creek, fall and winter 1995/1996

3.3 Mean $( \pm \mathrm{SE})$ total mercury concentrations $(\mu \mathrm{g} / \mathrm{g}$, wet wt.) in redbreast sunfish (Lepomis auritus) fillet samples collected from East Fork Poplar Creek, fall and winter 1995/1996 ( $\mathrm{N}=8$ at each site)

3.4 Comparison of mean total mercury and methylmercury concentrations $(\mu \mathrm{g} / \mathrm{g}$, wet wt.) in redbreast sunfish (Lepomis auritus) fillet and whole-body samples collected from East Fork Poplar Creek, December $1996(\mathrm{~N}=12)$ 


\section{TABLES}

1.1 Sites and tasks included in the baseline assessment

for the Lower East Fork Poplar Creek Postremediation Monitoring Program . . . . . . . 1-3

2.1 Sampling locations for water and sediment toxicity monitoring $\ldots \ldots \ldots \ldots \ldots \ldots \ldots .2$

2.2 Summary of results from Ceriodaphnia water toxicity tests conducted in August

(for the Biological Monitoring and Abatement Program) and November 1996

(for the Lower East Fork Poplar Creek Postremediation Monitoring Program) . . . . . . . 2-4

2.3 Summary of laboratory analyses of total mercury and methylmercury

for November 13,1996 , water samples . . . . . . . . . . . . . .

2.4 Summary of results from Hyalella sediment toxicity tests, May $7-17,1996 \ldots \ldots \ldots 2-7$

2.5 Summary of laboratory analyses of total mercury and methylmercury in sediments . . . 2-8

4.1 Total mercury $(\mathrm{Hg})$ and methylmercury $(\mathrm{MeHg})$ concentrations in soil, earthworms, and starlings from Lower East Fork Poplar Creek

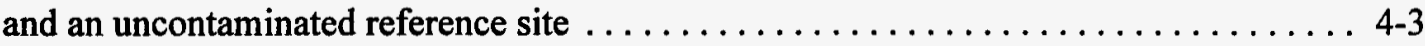

4.2 Starling population data collected from the Lower East Fork Poplar Creek

floodplain and an uncontaminated reference site during 1996

$4-4$

4.3 Starling population data collected from the Lower East Fork Poplar Creek and an uncontaminated reference site during 1997 


\section{ABBREVIATIONS}

BMAP Biological Monitoring and Abatement Program

DMC Document Management Center (for Environmental Management Program)

DOE U.S. Department of Energy

EFK East Fork Poplar Creek kilometer

EFPC East Fork Poplar Creek

ESD Environmental Sciences Division

HCK Hinds Creek (reference area) kilometer

$\mathrm{Hb}$ mercury

LEFPC Lower East Fork Poplar Creek

$\mathrm{MeHg}$ methylmercury

NOAA National Oceanic and Atmospheric Administration

PMP Postremediation Monitoring Program

RA remedial action

ROD Record of Decision

SAIC Science Applications International Corporation

TNEFK terrestrial (site) near East Fork Poplar Creek 


\section{EXECUTIVE SUMMARY}

Lower East Fork Poplar Creek (LEFPC) and its floodplain are contaminated with mercury $(\mathrm{Hg})$ from ongoing and historical releases from the U.S. Department of Energy (DOE) Oak Ridge Y-12 Plant. A remedial investigation and feasibility study of LEFPC resulted in the signing of a Record of Decision (ROD) in August 1995. In response to the ROD, soil contaminated with mercury above $400 \mathrm{mg} / \mathrm{kg}$ was removed from two sites in LEFPC and the floodplain during a recently completed remedial action (RA).

The chosen remediation goal in the LEFPC ROD of $400 \mathrm{mg} / \mathrm{kg}$ total mercury exceeds the preferred remediation goal option of $200 \mathrm{mg} / \mathrm{kg}$ for ecological receptors exposed via soil. The higher alternative was chosen because of concerns that remediation to the lower remediation goal option value could pose unacceptable harm to the environment. However, the LEFPC ROD acknowledged that uncertainties existed concerning the extent of remaining risks to the environment from this remediation choice. The ROD thus called for the implementation of a monitoring plan to ensure the protectiveness of the LEFPC ROD to ecological and human health. The Baseline and Postremediation Monitoring Program Plan for the Lower East Fork Poplar Creek Remedial Action Project, Oak Ridge, TN, Y/ER-262/R1, (SAIC 1996) (hereafter referred to as the "LEFPC Monitoring Plan") was prepared for DOE by Science Applications International Corporation (SAIC) under the requirements of the Comprehensive Environmental Response, Compensation, and Liability Act to describe the monitoring program stipulated in the ROD.

The Postremediation Monitoring Program (PMP) outlined in the LEFPC Monitoring Plan was envisioned to occur in two phases: (1) a baseline assessment prior to remediation and (2) postremediation monitoring. The current report summarizes the results of the baseline assessment of soil, water, biota, and groundwater usage in LEFPC and its floodplain conducted in 1995 and 1996 by personnel of the Oak Ridge National Laboratory Biological Monitoring and Abatement Program (BMAP). This report also includes some 1997 data from contaminated sites that did not undergo remediation during the RA (i.e., sites where mercury is greater than 200 $\mathrm{mg} / \mathrm{kg}$ but less than $400 \mathrm{mg} / \mathrm{kg}$ ). The baseline assessment described in this document is distinct and separate from both the remedial investigation/feasibility study and the confirmatory sampling conducted by SAIC during the RA. The purpose of the current assessment was to provide preremediation baseline data for the LEFPC PMP outlined in the LEFPC Monitoring Plan, using common approaches and techniques, as specified in that plan.

The PMP baseline assessment consisted of four major activities or tasks: (1) toxicity monitoring, (2) aquatic bioaccumulation studies, (3) terrestrial bioaccumulation studies involving soil and associated biota, and (4) a well monitoring activity. Study sites included locations in LEFPC and its floodplain and various uncontaminated reference sites.

Soil mercury remaining after remediation was considered in the ROD to be a potential source of continuing contamination to the surface waters and sediment of LEFPC. Toxicity tests during postremediation monitoring were to determine whether surface water and sediment mercury concentrations remained nontoxic to aquatic and sediment-dwelling biota following the RA. Evaluation of surface water and sediment concentrations of mercury were to accompany the toxicity evaluations. Postremediation monitoring of mercury and methylmercury ( $\mathrm{MeHg})$ in fish 
from East Fork Poplar Creek (EFPC) was to evaluate the potential remobilization of mercury in EFPC following the RA by examining the time-integrated ecological exposures of aquatic organisms. The primary objectives of the terrestrial bioaccumulation studies were to detect changes in biota exposure to soil mercury as sites recovered from remediation and determine if the chosen remediation goal was truly protective of terrestrial biota. Monitoring of groundwater usage in the LEFPC floodplain was to ensure the aquifer was not used in the future for drinking water purposes. Further description and rationales for these tasks may be found in the LEFPC Monitoring Plan.

The toxicity of water and sediment from LEFPC were characterized during this baseline assessment using the Cladoceran (Ceriodaphnia dubia) survival and reproduction test (for water) and the Hyalella azteca whole-sediment toxicity test. Water and sediment samples for mercury analysis were collected in conjunction with toxicity samples. Six LEFPC locations were sampled in order to bracket the areas being remediated; several of these locations also correspond to historical sampling locations for BMAP. A site in Hinds Creek served as a reference area for these studies. Ceriodaphnia toxicity tests were conducted during August 1996 (in conjunction with sampling for BMAP) and during November 1996. The Hyalella tests were conducted during May and November 1996.

Water from LEFPC did not reduce Ceriodaphnia survival or reproduction during either test period. These results, coupled with what is known about the dose-dependent toxicity of mercury in water to invertebrates, indicate that it is unlikely that water from LEFPC is now or ever will be acutely toxic to in-stream invertebrate biota. Sediment from LEFPC was not toxic to Hyalella in the May 1996 test. The results of the sediment toxicity tests indicate that the mercury at the measured concentrations was not toxic to Hyalella.

The results of the mercury analyses for surface water were in agreement with previous monitoring results (LMES 1995, 1996). Concentrations of total mercury were highest in water samples collected from the uppermost sites in EFPC and declined with distance downstream [e.g., $520 \mathrm{ng} / \mathrm{L}$ at East Fork Poplar Creek kilometer (EFK) 22.8 and $101 \mathrm{ng} / \mathrm{L}$ at EFK 13.8]. In contrast, concentrations of methylmercury tended to increase with distance downstream (e.g., $0.056 \mathrm{ng} / \mathrm{L}$ at EFK 22.8 and $0.123 \mathrm{ng} / \mathrm{L}$ at EFK 13.8). The exception was EFK 21.9, immediately. downstream of the National Oceanic and Atmospheric Administration (NOAA) remediation site, where the methylmercury concentration in surface water was approximately 1.5 times higher than at the sites immediately upstream (EFK 22.8) and downstream (EFK 18.2).

Total mercury and methylmercury concentrations were determined prior to the RA in three fish species representing three different functional feeding groups at LEFPC sites bracketing the remediation areas. In general, the two forage species accumulated very different levels of mercury and exhibited major differences in the fraction of total mercury that was methylmercury (the most toxic mercury form). The central stoneroller accumulated high concentrations of total mercury in the upper section of EFPC, but relatively little of that mercury was methylmercury. In contrast, the total mercury concentrations in striped shiner were generally lower than those found in stonerollers at the three most upstream sites, but a much higher percentage of the total consisted of the methylmercury form. Concentrations of the much less toxic inorganic mercury in both forage species were high enough (40-90\%) that evaluations of risk to piscivorous wildlife based on assumptions of $100 \%$ methylmercury in forage species are likely to be substantially overestimated. 
There were no significant differences in mean mercury concentrations measured in sunfish fillets sampled upstream and downstream of the remediation sites prior to the RA. In a comparison of fillet versus whole-body analytical techniques, sunfish fillet concentrations of total mercury did not differ significantly from the total concentrations in whole fish bodies. However, less than half of the total mercury in sunfish whole bodies was of the methylmercury form. Based on this study, it is proposed that sunfish fillet concentrations, as routinely collected by BMAP throughout EFPC (for human health assessment), should be divided approximately in half to provide estimates of methylmercury concentrations in sunfish whole bodies for ecological risk evaluation purposes.

As anticipated, an assessment of mercury uptake by earthworms and starlings at LEFPC sites suggested that methylmercury concentrations are higher in earthworms than in soil and higher still in starlings. Concentrations of methylmercury in earthworms and starlings were generally higher at sites where soil concentrations of mercury were higher. To date, higher mercury or methylmercury concentrations have not been shown to impact clutch size, fledgling success, or nestling weight. However, significant predation losses and lack of nesting activity at the most contaminated sites precluded the drawing of definitive conclusions about the impact of mercury contamination in the LEFPC floodplain on starling reproduction. For this reason, further investigation of this problem is recommended during the postremediation period under a modified monitoring plan that takes into account lessons learned during this baseline assessment.

Since any use of groundwater from the LEFPC floodplain as drinking water could pose an unacceptable risk to human health, the LEFPC ROD specified monitoring to ensure continuing nonusage of the groundwater for drinking water. As specified in the LEFPC Monitoring Plan, a visual surveillance of the LEFPC floodplain was conducted to provide information to DOE as to the presence of new groundwater wells in the floodplain. At DOE's request, the state's well drilling report database was also obtained from the Division of Water Supply of the Tennessee Department of Environment and Conservation in Nashville and provided to DOE. Based on our experience of attempting to monitor new well construction by conducting the visual survey of well usage specified in the LEFPC Monitoring Plan, we recommend the discontinuation of visual surveys and a reliance on the state's well drilling report database for any future surveillance of groundwater usage in the LEFPC floodplain. 


\section{INTRODUCTION}

Lower East Fork Poplar Creek (LEFPC) and its floodplain are contaminated with mercury from ongoing and historical releases from the U.S. Department of Energy (DOE) Oak Ridge Y-12 Plant. A remedial investigation and feasibility study of LEFPC resulted in the signing of a Record of Decision (ROD) in August 1995. In response to the ROD, soil contaminated with mercury above 400 $\mathrm{mg} / \mathrm{kg}$ was removed from two sites [National Oceanic and Atmospheric Administration (NOAA) and Bruner] in LEFPC and the floodplain during a recently completed remedial action (RA).

The chosen remediation goal in the LEFPC ROD of $400 \mathrm{mg} / \mathrm{kg}$ total mercury exceeds the preferred remediation goal option of $200 \mathrm{mg} / \mathrm{kg}$ for ecological receptors exposed via soil. The higher alternative was chosen because of concerns that remediation to the lower remediation goal option value could pose unacceptable harm to the environment. However, the LEFPC ROD acknowledged that uncertainties existed concerning the extent of remaining risks to the environment from this remediation choice. The ROD thus called for the implementation of a monitoring plan to ensure the protectiveness of the LEFPC ROD to ecological and human health. The Baseline and Postremediation Monitoring Program Plan for the Lower East Fork Poplar Creek Remedial Action Project, Oak Ridge, TN, Y/ER-262/R1, (SAIC 1996) (hereafter referred to as the "LEFPC Monitoring Plan") was prepared for DOE by Science Applications International Corporation (SAIC) under the requirements of the Comprehensive Environmental Response, Compensation, and Liability Act to describe the monitoring program stipulated in the ROD.

The Postremediation Monitoring Program (PMP) outlined in the LEFPC Monitoring Plan was envisioned to occur in two phases: (1) a baseline assessment prior to remediation and (2) postremediation monitoring. The current report summarizes the results of the baseline assessment of soil, water, biota, and groundwater usage in LEFPC and its floodplain conducted in 1995 and 1996 by personnel of the Oak Ridge National Laboratory Biological Monitoring and Abatement Program (BMAP). This report also includes some 1997 data from contaminated sites not scheduled to undergo remediation during the RA (i.e., sites where mercury is greater than $200 \mathrm{mg} / \mathrm{kg}$ but less than $400 \mathrm{mg} / \mathrm{kg}$ ). The baseline assessment described in this document is distinct and separate from both the remedial investigation/feasibility study and the confirmatory sampling conducted by SAIC during the RA. The purpose of the current assessment was to provide preremediation baseline data for the LEFPC PMP outlined in the LEFPC Monitoring Plan, using common approaches and techniques, as specified in that plan. Figure 1.1 shows sites included in the baseline assessment for the LEFPC PMP.

The PMP baseline assessment consisted of four major activities or tasks: (1) toxicity monitoring, (2) aquatic bioaccumulation studies, (3) terrestrial bioaccumulation studies involving soil and associated biota, and (4) a well monitoring activity. Study sites included locations in LEFPC and its floodplain and various uncontaminated reference sites. See Table 1.1 for a breakdown of sites and tasks included in the baseline assessment for the LEFPC PMP.

Soil mercury remaining after remediation was considered in the ROD to be a potential source of continuing contamination to the surface waters and sediment of LEFPC. Toxicity tests during postremediation monitoring were to determine whether surface water and sediment mercury concentrations remained nontoxic to aquatic and sediment-dwelling biota following the RA. Evaluation of surface water and sediment concentrations of mercury were to accompany the toxicity 


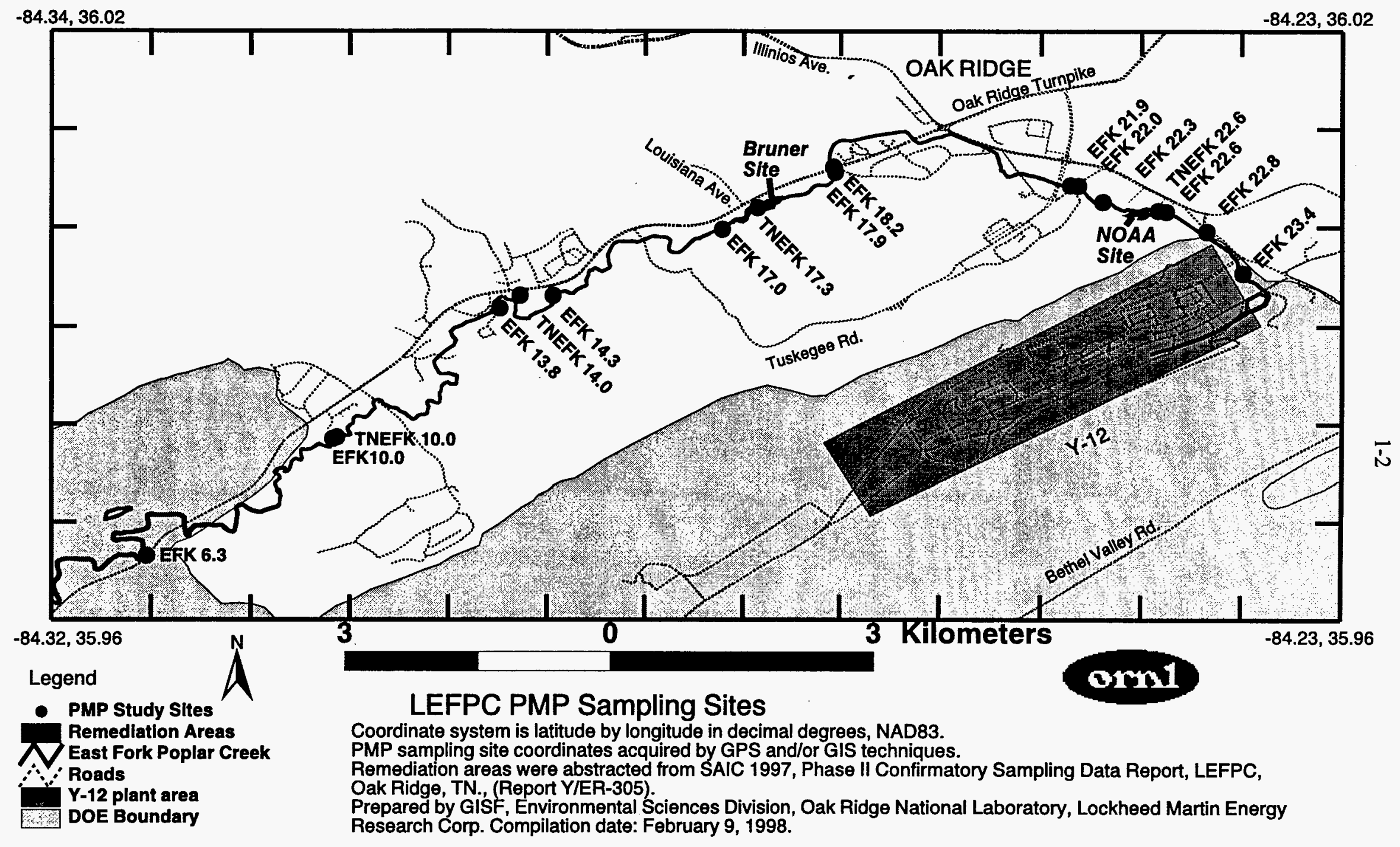

Fig. 1.1. Map of sampling sites included in the baseline assessment for the Lower East Fork Poplar Creek Postremediation Monitoring Program. 
Table 1.1. Sites and tasks included in the baseline assessment for the Lower East Fork Poplar Creek Postremediation Monitoring Program

\begin{tabular}{|c|c|c|c|c|c|c|c|}
\hline \multirow[b]{2}{*}{ Toxicity-Water } & \multirow[b]{2}{*}{ EFK 22.8} & \multicolumn{4}{|c|}{ Sites $^{a}$} & \multicolumn{2}{|r|}{ Reference } \\
\hline & & EFK 21.9 & EFK 18.2 & EFK 17.0 & EFK 13.8 & EFK 10.0 & HCK 20.6 \\
\hline Toxicity- sediment & EFK 22.6 & EFK 22.3 & EFK 17.9 & EFK 17.0 & EFK 14.3 & EFK 10.0 & HCK 20.6 \\
\hline $\mathrm{Hg}$-water & EFK 22.8 & EFK 21.9 & EFK 18.2 & EFK 17.0 & EFK 13.8 & EFK 10.0 & HCK 20.6 \\
\hline Hg-sediment & EFK 22.6 & EFK 22.3 & EFK 17.9 & EFK 17.0 & EFK 14.3 & EFK 10.0 & HCK 20.6 \\
\hline Bioaccumulation-forage fish & EFK 23.4 & EFK 22.0 & EFK 18.2 & EFK 13.8 & EFK 6.3 & & HCK 20.6 \\
\hline $\begin{array}{l}\text { Bioaccumulation-fillet/ } \\
\text { whole-body ratio }\end{array}$ & EFK 23.4 & EFK 22.0 & EFK 18.2 & EFK 13.8 & EFK 6.3 & & HCK 20.6 \\
\hline Bioaccumulation-sunfish & EFK $23.4^{b}$ & EFK 22.0 & EFK $18.2^{b}$ & EFK $13.8^{b}$ & EFK $6.3^{b}$ & & HCK $20.6^{b}$ \\
\hline Bioaccumulation-earthworms/soil & TNEFK 22.6 & TNEFK 17.3 & TNEFK 14.0 & TNEFK 10.0 & & & TFREELSBD1 \\
\hline Bioaccumulation-starlings & TNEFK 22.6 & TNEFK 17.3 & TNEFK 14.0 & TNEFK 10.0 & & & TFREELSBD1 \\
\hline Population studies-starling & TNEFK 22.6 & TNEFK 17.3 & TNEFK 14.0 & TNEFK 10.0 & & & TFREELSBD1 \\
\hline Groundwater use monitoring & \multicolumn{7}{|c|}{$\begin{array}{l}\text { Approximately EFK } 21.0 \text { - EFK } 8.0 \text { (private property within the EFPC floodplain); task as proposed involves nc } \\
\text { actual field work at these sites }\end{array}$} \\
\hline
\end{tabular}

${ }^{a}$ EFK = East Fork Poplar Creek kilometer; HCK = Hinds Creek kilometer; TNEFK = terrestrial (site) near EFK; TFREELSBD1 = terrestrial (site) at Freels Bend on the Oak Ridge Reservation

${ }^{b}$ Sites funded by Y-12 Environmental Compliance Office for Y-12 Biological Monitoring and Abatement Program purposes; data available to the Postremediation Monitoring Program 
evaluations. Postremediation monitoring of mercury and methylmercury $(\mathrm{MeHg})$ in fish from East Fork Poplar Creek (EFPC) was to evaluate the potential remobilization of mercury in EFPC following the RA by examining the time-integrated ecological exposures of aquatic organisms. The primary objectives of the terrestrial bioaccumulation studies were to detect changes in biota exposure to soil mercury as sites recovered from remediation and determine if the chosen remediation goal was truly protective of terrestrial biota. Monitoring of groundwater usage in the LEFPC floodplain was to ensure the aquifer was not used in the future for drinking water purposes. Further description and rationales for these tasks may be found in the LEFPC Monitoring Plan. 


\section{TOXICITY MONITORING}

\subsection{INTRODUCTION}

Toxicity monitoring of water and sediment were conducted to fulfill the preremediation requirements in the LEFPC Monitoring Plan for evaluating (1) the toxicity of EFPC surface water to aquatic biota relative to surface water from a reference site and relative to a laboratory control (measurement endpoint 7 in the plan) and (2) the toxicity of EFPC to sediment-dwelling organisms relative to sediments from a reference site and relative to a laboratory control (measurement endpoint 6). Measurements of total mercury and methylmercury in water and sediment were made in conjunction with the toxicity tests to fulfill the LEFPC Monitoring Plan requirements for measurement endpoint 8.

\subsection{MATERIALS AND METHODS}

\subsubsection{Water}

The Cladoceran (Ceriodaphnia dubia) survival and reproduction test [hereafter referred to as the Ceriodaphnia test (Lewis et al. 1994)] was used to characterize the toxicity of water from LEFPC. The Ceriodaphnia test was a static-renewal test, where test water was replaced daily for 6 or 7 consecutive days. There were ten replicates per water sample with one animal per replicate. Each day the animals were transferred from a beaker containing old test solution and placed in a beaker containing fresh test solution. At this time, survival and number of offspring produced were recorded. A control consisting of $25 \%$ dilute mineral water augmented with trace metals was included with each test. On each fresh sample, subsamples of each effluent were analyzed for $\mathrm{pH}$, conductivity, alkalinity, and water hardness. Detailed test procedures are located in Kszos et al. (1996).

The sampling locations for the water tests are identified in Table 2.1. Six LEFPC locations were sampled in order to bracket the areas being remediated; several of these locations correspond to historical sampling locations for BMAP. The Hinds Creek location served as a reference site. Three grab samples were obtained from each site over the 6-d test period. Each sample was used immediately then placed in refrigerated storage and used for 1 or 2 additional test days. Detailed sampling procedures are located in Kszos et al. (1996).

Water samples for total mercury analysis were collected in 250-mL Teflon bottles supplied by the analytical laboratory (Brooks Rand). Samples for methylmercury were collected by filtering $250-\mathrm{mL}$ of water through a sterilized, Nalgene, disposable filter unit $(0.45-\mu \mathrm{m}$ pore size). Following filtration, the sample was transferred to a $250-\mathrm{mL}$ Teflon bottle. All mercury samples were collected and processed in the field and were immediately placed on ice following collection. The samples were shipped via overnight courier to the analytical laboratory the same day they were collected.

Ceriodaphnia toxicity tests with water from East Fork Poplar Creek kilometers (EFKs) 10.0, $13.8,18.2,20.5,21.9$, and 22.8 were conducted on a routine basis during 1986-1996 as part of BMAP. These data are available in Loar (1992) and Hinzman (1993, 1996). Because historical data for these sites existed and BMAP data from February 1996 were available (Greeley 1996), it was determined that one additional sampling event immediately prior to the startup of remediation 
activities would fulfill preremediation requirements. Thus, a Ceriodaphnia toxicity test was conducted during November 13-19, 1996. Grab samples for the toxicity test were collected on November 13, 16, and 18, 1996. Samples for analysis of mercury and methylmercury were collected on November 13, 1996.

Table 2.1. Sampling locations for water and sediment toxicity monitoring

\begin{tabular}{|c|c|c|}
\hline Location $^{a}$ & Media & Purpose \\
\hline HCK 20.6 & Water and sediment & Reference site \\
\hline EFK 22.8 & Water and sediment & $\begin{array}{l}\text { Establish preremediation baseline for EFPC upstream of NOAA } \\
\text { site }\end{array}$ \\
\hline EFK 21.9 & Water & $\begin{array}{l}\text { Establish preremediation baseline for EFPC downstream of NOAA } \\
\text { site }\end{array}$ \\
\hline EFK 21.6 & Sediment & \\
\hline EFK 18.2 & Water & Establish preremediation baseline for EFPC upstream of Bruner site \\
\hline EFK 17.9 & Sediment & \\
\hline EFK 17.0 & Water and sediment & $\begin{array}{l}\text { Establish preremediation baseline for EFPC downstream of Bruner } \\
\text { site }\end{array}$ \\
\hline EFK 14.3 & Sediment & Confirm lack of effects at exposure $>50 \mathrm{ppm}$ but $<200 \mathrm{ppm} \mathrm{Hg}$ \\
\hline EFK 13.8 & Water & \\
\hline EFK $10.0^{b}$ & Water and sediment & Confirm lack of effects at exposure $>200 \mathrm{ppm}$ but $<400 \mathrm{ppm} \mathrm{Hg}$ \\
\hline
\end{tabular}

Statistical analyses of the Ceriodaphnia reproduction data and the Hyalella survival data were accomplished using the Statistical Analyses System (SAS 1985). Only data for those Ceriodaphnia surviving the entire test were used in the statistical analyses for reproductive endpoints. The normality of the data was determined using Shapiro-Wilks test for normality. Neither the Ceriodaphnia reproduction data nor the Hyalella survival data were normally distributed; thus, differences in Ceriodaphnia reproduction and Hyalella survival between test sites and the control or the reference site were determined using a nonparametric test (Wilcoxon Rank Sum or Steel's Many-One Rank test).

\subsubsection{Sediment}

The sampling locations for the sediment tests are identified in Table 2.1. Six LEFPC locations were sampled in order to bracket the areas being remediated and to correspond as closely as possible with the locations for the water toxicity tests. The Hinds Creek location served as a reference site. The Hyalella azteca whole-sediment toxicity test [hereinafter referred to as the Hyalella test (EPA 1994)] was used to characterize the toxicity of sediment from LEFPC. The Hyalella test was a static-renewal test, meaning that the overlying test water is replaced daily for 10 consecutive days. There were four replicates per sediment sample, with ten animals per replicate. A laboratory-formulated sediment control was included with each test. The control sediment consisted 
of equal parts of sand $(<0.5 \mathrm{~mm})$, purchased locally, and clay collected from a uncontaminated pond in the area of the Environmental Sciences Division at Oak Ridge National Laboratory. The mixture was homogenized until thoroughly mixed and then held in the dark at $4 \pm 2{ }^{\circ} \mathrm{C}$ until used.

Each day of the toxicity test, the overlying water was siphoned from each replicate and replaced with fresh water. The overlying water was $30 \%$ dilute mineral water augmented with trace metals. On days 1 and 9 of the test, the siphoned, overlying water was analyzed for $\mathrm{pH}$, conductivity, alkalinity, hardness, and dissolved oxygen. On days 2-8 and 10, conductivity, dissolved oxygen, and $\mathrm{pH}$ were measured. Ammonia analyses were also performed on subsamples of the overlying water on days 1 and 9. Detailed test procedures are located in Kszos et al. (1996).

Sediment samples were obtained at each site using a Ponar dredge sampling device and stainless-steel tray. Prior to sampling, the stainless-steel tray was thoroughly rinsed with ambient water from the site. At each site, a grab sample(s) was placed into the rinsed tray, and large pieces of debris (sticks, rocks, leaves, etc.) were removed. The sample was then homogenized and transferred either into a 30-mL Teflon bottle for mercury analyses (see below) or a 1-L, high-density polyethylene bottle for use in the toxicity test; the time and date were recorded on the field sampling chain-of-custody form. Excess sediment was returned to the creek, and the stainless steel tray was thoroughly cleaned with ambient water.

Samples obtained for mercury analysis were splits from the grab sample used for the toxicity tests. The transfer of the sample for mercury analyses occurred prior to transfer of the sample for toxicity testing into the high-density polyethylene bottles. Clean techniques were used for collecting the mercury samples to prevent contamination of the sample containers and sample. Two samplers donned new, clean latex gloves prior to handling the sample or sample containers. One sampler was designated as "dirty," and the other was designated "clean." The "clean" sampler only handled the sample container (precleaned $30 \mathrm{~mL}$ Teflon bottle sealed within two resealable plastic bags, which were provided by the analytical laboratory responsible for the mercury analyses). The "clean" sampler touched only the sample bottles and bags until the sample was placed into the container, the container was closed, and the protective bags were sealed. The "dirty" sampler transferred the sediment into the sample container (never coming into contact with the sample container). This process was carried out at each new sampling site.

Whole-sediment toxicity tests had not been previously conducted at any of the LEFPC sites; thus, two sampling events were conducted prior to the start of remediation activities. Grab samples for the toxicity test and mercury analyses were collected on May 1, 1996, and November 8, 1996. The samples for mercury analyses were shipped via overnight courier to the analytical laboratory the same day they were collected. The samples for the toxicity tests were immediately refrigerated and held for 4 to 6 days. The Hyalella tests were conducted during May 7-17, 1996, and November 12-22, 1996.

\subsection{RESULTS}

\subsubsection{Water}

The results of the Ceriodaphnia toxicity tests are provided in Table 2.2. Results of the toxicity test conducted for BMAP in August 1996 are also provided in Table 2.2. Reproduction in water from EFPC was not significantly different from reproduction in the control or from the reference site (Wilcoxon Rank Sum test). Mean reproduction in water from EFPC sites collected in August 1996 
ranged from 28.7 to 33.3 offspring/female, which, with the exception of one site, was higher than mean reproduction in the control (29.4 offspring/female). Mean reproduction in water from EFPC sites collected in November 1996 ranged from 29.3 to 32.1 offspring/female, which was higher than mean reproduction in the control (23.7 offspring/female) and in the reference site (24.5 offspring/female).

Table 2.2. Summary of results from Ceriodaphnia water toxicity tests conducted in August (for the Biological Monitoring and Abatement Program) and November 1996 (for the Lower East Fork Poplar Creek Postremediation Monitoring Program)

\begin{tabular}{|c|c|c|}
\hline Site ${ }^{a}$ & Survival (\%) & $\begin{array}{l}\text { Mean number of offspring per } \\
\text { surviving female }( \pm S D)\end{array}$ \\
\hline \multicolumn{3}{|c|}{ August 14-20, 1996} \\
\hline Control & 90 & $29.4 \pm 5.5$ \\
\hline EFK 22.8 & 100 & $30.5 \pm 4.2$ \\
\hline EFK 21.9 & 100 & $33.3 \pm 2.7$ \\
\hline EFK 18.2 & 100 & $28.7 \pm 3.0$ \\
\hline EFK 17.0 & Not tested & Not tested \\
\hline EFK 13.8 & 100 & $32.3 \pm 2.8$ \\
\hline EFK 10.0 & 100 & $31.9 \pm 1.9$ \\
\hline HCK 20.6 & Not tested & Not tested \\
\hline \multicolumn{3}{|c|}{ - November 13-19, 1996} \\
\hline Control & 100 & $23.7 \pm 11.6$ \\
\hline EFK 22.8 & 80 & $32.1 \pm 4.5$ \\
\hline EFK 21.9 & 100 & $29.3 \pm 7.9$ \\
\hline EFK 18.2 & 90 & $31.4 \pm 4.2$ \\
\hline EFK 17.0 & 90 & $31.9 \pm 1.6$ \\
\hline EFK 13.8 & 90 & $30.3 \pm 8.2$ \\
\hline EFK 10.0 & 100 & $31.8 \pm 3.6$ \\
\hline HCK 20.6 & 100 & $24.5 \pm 9.7$ \\
\hline
\end{tabular}

${ }^{a}$ EFK = East Fork Poplar Creek kilometer; HCK = Hinds Creek kilometer reference site

Results of the mercury analyses for water collected at the same sites for the toxicity tests are included in Table 2.3. Concentrations of total mercury were higher in water samples collected from sites in upper EFPC and declined with distance downstream. Except for EFK 21.9, concentrations of methylmercury increased with distance downstream. The methylmercury concentration in EFK 21.9, one of the sites to be remediated, was approximately twofold higher than the site immediately upstream (EFK 22.8). The mercury data for LEFPC collected for preremediation compare well with data in LMES 1995 and 1996 (Fig. 2.1). 
Table 2.3. Summary of laboratory analyses of total mercury and methylmercury for November 13, 1996, water samples

\begin{tabular}{ccc}
\hline Site $^{\alpha}$ & Total Hg (ng/L) & MeHg (ng/L) \\
\hline EFK 22.8 & 520 & 0.056 \\
EFK 21.9 & 483 & 0.116 \\
EFK 18.2 & 206 & 0.079 \\
EFK 17.0 & 197 & 0.101 \\
EFK 13.8 & 101 & 0.123 \\
EFK 10.0 & 90.6 & 0.187 \\
HCK 20.6 & 0.55 & 0.040 \\
\hline
\end{tabular}

${ }^{a}$ EFK = East Fork Poplar Creek kilometer; HCK = Hinds Creek kilometer reference site

To evaluate the precision of the analytical method, water samples from two EFPC sites were split in the field. Samples of water from EFK 10.0 were collected and analyzed for total mercury and samples from EFK 17.0 were analyzed for methylmercury. Total mercury concentrations in the samples from EFK 10.0 were 90.6 and $95.0 \mathrm{mg} / \mathrm{L}$; the relative percent difference was $4.6 \%$.

Methylmercury concentrations in the samples from EFK 17.0 were 0.101 and $0.087 \mathrm{ng} / \mathrm{L}$; the relative percent difference was $13.9 \%$. Deionized, distilled water was used to collect a filter blank. A sample of the deionized water was submitted for analysis of total mercury. The total mercury concentration in the source water was less than the method detection limit. The filter blank was analyzed for methylmercury. The concentration of methylmercury in the filter blank was $0.046 \mathrm{ng} / \mathrm{L}$. This result was above the method detection limit but was less than the quantitation limit and is therefore considered an estimate.

\subsubsection{Sediment}

Results of the Hyalella test in May 1996 are presented in Table 2.4. Survival in the LEFPC sites was compared to both survival in the laboratory control sediment and in reference site sediment. Survival of Hyalella in the control sediment during the November 1996 test was unacceptable; thus, results of this test are not discussed. The results of the rank test indicated that there were no significant differences in survival between the LEFPC sites and the reference site or between the LEFPC sites and the laboratory control. Hyalella survival in sediment from EFK 14.3 was the lowest of all the sites (57.5\%) and was more than $20 \%$ less than survival in Hinds Creek sediment. However, there was considerable replicate variability in this sample. The proportion of Hyalella surviving in each replicate of sediment from EFK 14.3 was $0.7,0.1,0.7$, and 0.8 . Thus, the low mean proportion surviving was highly dependant on low survival in one replicate. 

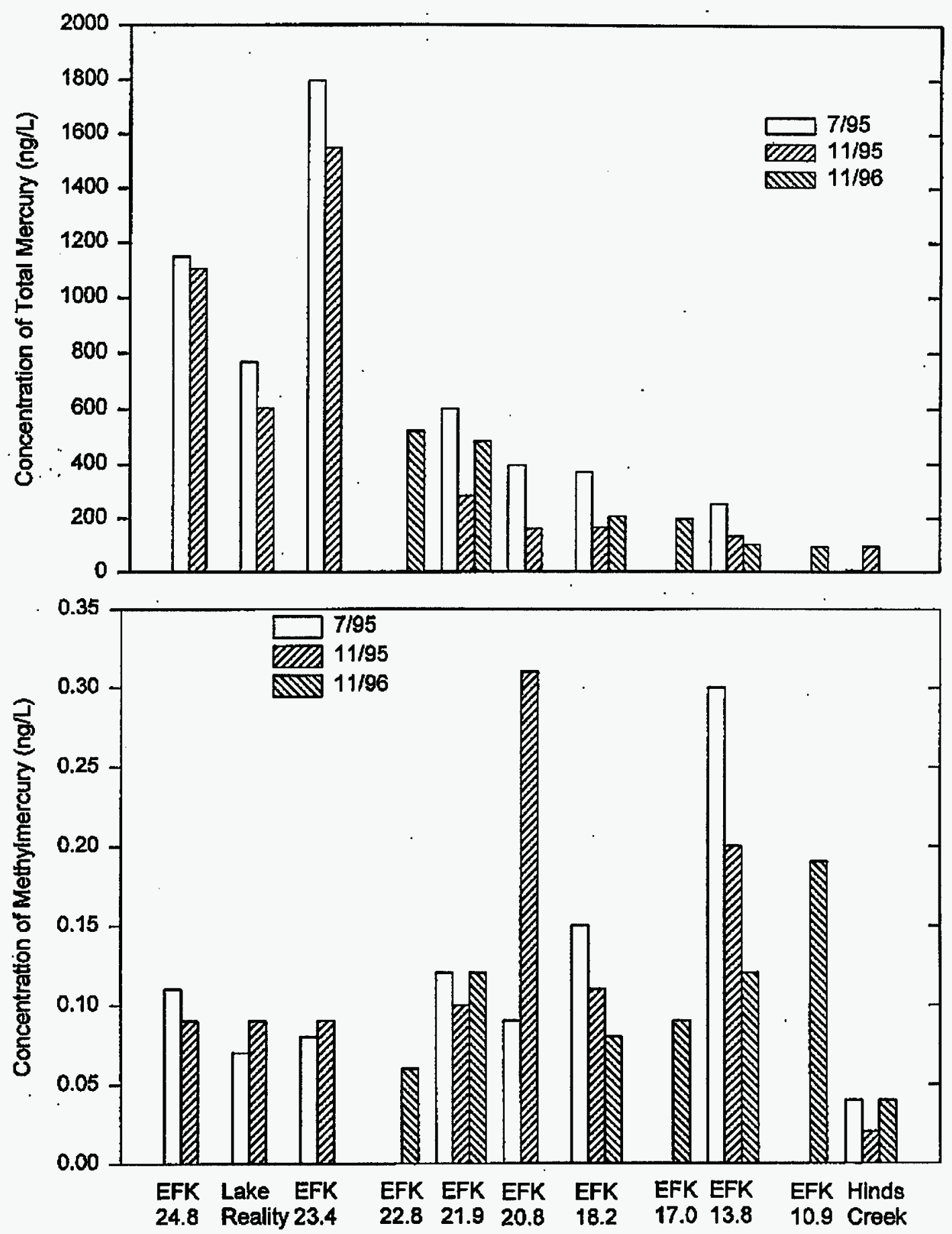

Fig. 2.1. Total mercury (top) and methylmercury (bottom) in surface water from East Fork Poplar Creek and Hinds Creek. The data are from 1995 samples and are presented in LMES 1995 and 1996. EFK = East Fork Poplar Creek kilometer. 
Table 2.4. Summary of results from Hyalella sediment toxicity tests, May 7-17, 1996

\begin{tabular}{cccc}
\hline Site ${ }^{\text {a }}$ & Survival (\%) & $\begin{array}{c}\text { Percent difference } \\
\text { from HCK 20.6 } \\
\text { Survival = 73.3\% }\end{array}$ & $\begin{array}{c}\text { Percent difference } \\
\text { from control } \\
\text { survival = 92.5\% }\end{array}$ \\
\hline Control & 92.5 & 28.2 & NA \\
EFK 22.6 & 87.5 & 19.4 & -5.4 \\
EFK 22.3 & 70.0 & -4.5 & -24.3 \\
EFK 17.9 & 70.0 & -4.5 & -24.3 \\
EFK 17.0 & 70.0 & -4.5 & -24.3 \\
EFK 14.3 & 57.5 & -21.6 & -37.8 \\
EFK 10.0 & 92.5 & 26.2 & 0.0 \\
HCK 20.6 & 73.3 & NA & -20.8 \\
\hline
\end{tabular}

${ }^{a}$ EFK = East Fork Poplar Creek kilometer; HCK $=$ Hinds Creek kilometer reference site

To evaluate the precision of the test method, a split sediment sample from one EFPC site was collected for each sampling event. Sediment from EFK 17.0 was split for the May test, and sediment from Hinds Creek kilometer (HCK) 20.6 was split for the November test. Mean percent survival in the split samples was equal to survival in the test samples for both test periods. Results of the mercury analyses of sediment are given in Table 2.5. The results from one sampling event to the other are quite variable. For example, in May 1996, total mercury at EFK 17.0 was the highest at any site $(78,888 \mathrm{ng} / \mathrm{g}$ dry wt), and in the November 1996 samples, total mercury at this site was 12,057 $\mathrm{ng} / \mathrm{g}$. Large differences were noted for most sites in concentrations of total and methylmercury. To evaluate the homogeneity of the sediment sample and the precision of the analytical method, a split sediment sample from one EFPC site was collected during each sampling event. Field split samples of sediment from EFK 17.0 and HCK 20.6 were collected and analyzed for total mercury and methylmercury. Total mercury concentrations in the samples from EFK 17.0 were $78,888 \mathrm{ng} / \mathrm{g}$ and $70,882 \mathrm{ng} / \mathrm{g}$; the relative percent difference was $10 \%$. Total mercury concentrations in the samples from HCK 20.6 were $33.2 \mathrm{ng} / \mathrm{g}$ and $33.8 \mathrm{ng} / \mathrm{g}$; the relative percent difference was $1.8 \%$. Methylmercury concentrations in the samples from EFK 17.0 were $16.5 \mathrm{ng} / \mathrm{g}$ and $11.2 \mathrm{ng} / \mathrm{g}$; the relative percent difference was $32 \%$. Methylmercury concentrations in the samples from HCK 20.6 were $0.70 \mathrm{ng} / \mathrm{g}$ and $0.792 \mathrm{ng} / \mathrm{g}$; the relative percent difference was $11.6 \%$.

\subsection{DISCUSSION}

Water from LEFPC did not reduce Ceriodaphnia survival or reproduction during August or November 1996. These results indicate that water from LEFPC is probably not toxic to in-stream invertebrate biota; however, it is possible that invertebrates more sensitive that Ceriodaphnia could be adversely affected by poor water quality. The results of the mercury analyses for surface water were in agreement with previous monitoring (LMES 1995, 1996). The trends for total mercury and methylmercury in water were similar to those observed for fish (see Chap. 3 of this report) in that concentrations declined with distance downstream. For a more thorough discussion of mercury in surface water and mercury in fish, see LMES 1995, 1996, 1997. 
Table 2.5. Summary of laboratory analyses of total mercury and methylmercury in sediments

\begin{tabular}{|c|c|c|}
\hline Site ${ }^{a}$ & $\begin{array}{c}\text { Total } \mathrm{Hg} \\
\text { (ng/g dry weight) }\end{array}$ & $\begin{array}{c}\text { MeHg } \\
\text { (ng/g dry weight) }\end{array}$ \\
\hline \multicolumn{3}{|c|}{ May 1,1996} \\
\hline EFK 22.6 & 27,140 & 10.6 \\
\hline EFK 22.3 & 25,312 & 5.63 \\
\hline EFK 17.9 & 37,795 & 34.7 \\
\hline EFK 17.0 & 78,888 & 16.5 \\
\hline EFK 14.3 & 34,543 & 5.91 \\
\hline EFK 10.0 & 4,618 & 4.57 \\
\hline HCK 20.6 & 45.8 & 2.56 \\
\hline Laboratory control & 72.7 & 0.181 \\
\hline \multicolumn{3}{|c|}{ November 8, 1996} \\
\hline EFK 22.6 & 6,488 & 1.03 \\
\hline EFK 22.3 & 54,522 & 3.38 \\
\hline EFK 17.9 & $-b$ & - \\
\hline EFK 17.0 & 12,058 & 4.72 \\
\hline EFK 14.3 & 2,243 & 1.39 \\
\hline EFK 10.0 & 5,204 & 2.25 \\
\hline HCK 20.6 & 33.2 & 0.7 \\
\hline Laboratory control & 28.7 & 0.110 \\
\hline
\end{tabular}

${ }^{a}$ EFK $=$ East Fork Poplar Creek kilometer; HCK = Hinds Creek kilometer reference site

${ }^{b}$ Not sampled; sufficient sediment was not available at this location

Sediment from LEFPC did not reduce Hyalella survival during the May 1996 test. The results of the sediment toxicity tests indicate that there was no correlation of total mercury concentration in sediment with toxicity to Hyalella. In some cases, mortality was greater in those sites with lower concentrations of mercury. The relative percent difference in the mercury and methylmercury concentrations between the field splits for sediment indicates that the sediment used in the toxicity tests was not necessarily homogeneous. This is not surprising because the sediment in LEFPC is quite rocky and difficult to homogenize. In addition, sediment for toxicity tests is typically disturbed as little as possible such that ambient conditions are imitated as much as possible. Thus, sediment samples obtained for mercury analyses should be obtained from a separate, well-homogenized sample rather than from a split of the toxicity test sample. 


\section{AQUATIC BIOACCUMULATION TASK}

\subsection{INTRODUCTION}

Fish were collected in the fall and winter of 1995/1996 from locations in EFPC and a reference site and were analyzed for total mercury and methylmercury. The aquatic bioaccumulation task of PMP was designed to evaluate potential changes in mercury exposure to biota in the stream resulting from the major earthmoving activities associated with the LEFPC RA. The absence of increases in mercury concentrations in fish following remediation would provide evidence that mercury was not significantly remobilized in the stream. Further description and rationale for the Aquatic Bioaccumulation Task are found in the LEFPC Monitoring Plan (SAIC 1996).

\subsection{MATERIALS AND METHODS}

Three whole-body composite samples of striped shiners (Luxilus chrysocephalus) and three composite samples of central stonerollers (Campostoma anomalum) were analyzed for total mercury and methylmercury at each of five EFPC sites (EFK 23.4, 22.0, 18.2, 13.8, 6.3) and the reference stream (Hinds Creek) in the fall and winter of 1995/1996. This sampling constituted a baseline fish collection prior to remediation. At each site, forage fish were collected by electrofishing and grouped into three subgroups containing ten fish of a similar size range. Individuals in each subgroup were weighed and measured, and the sample of ten whole fish was then homogenized in a stainless steel blender and packaged in aluminum foil for delivery to the analytical laboratory. Samples were processed according to project-specific, standardized technical procedures developed by BMAP to ensure quality and integrity (Peterson and Phipps 1997).

Total mercury in redbreast sunfish (Lepomis auritus) fillets (eight fish/site) was determined at the same sites. Five of the six sunfish sites were collected for and funded by the Y-12 BMAP; the NOAA site (EFK 22.0) is not a routine BMAP site and was supported by the LEFPC project. Sunfish fillet data was used to evaluate changes in human health risks and to estimate whole-body concentrations in sunfish (to address eco-risk concerns). Fillet tissue was excised from each fish, wrapped in aluminum foil, and delivered to the analytical laboratory. As was the case with forage fish, sunfish samples were processed according to project-specific technical procedures (Peterson and Phipps 1997).

A one-time analysis of total mercury and methylmercury in sunfish fillets and whole bodies was conducted so that BMAP fillet data could be used in future years to predict mercury concentrations in sunfish whole bodies. Four redbreast sunfish were collected from each of three EFPC sites (EFK 22.0, EFK 18.2, and EFK 13.8) during the first week of December 1996. Upon return to the laboratory, a fillet sample of muscle tissue was excised from each fish. These samples, and the remaining carcasses, were weighed and then frozen prior to homogenization and subsequent submission to a commercial laboratory for total mercury and methylmercury analyses.

Sunfish collected from EFPC in fall and winter 1995/1996 were analyzed for total mercury by cold-vapor atomic absorption spectrophotometry following digestion in HNO3/H2SO4 (EPA 1991, procedure 245.6). All other samples were analyzed for total mercury and methylmercury using aqueous-phase ethylation followed by cryogenic-gas chromatography with cold-vapor atomic fluorescence detection (Bloom 1989). 


\subsection{RESULTS}

The central stoneroller, an abundant herbivorous minnow in EFPC, accumulated high concentrations ( $21 \mu \mathrm{g} / \mathrm{g}$ ) of total mercury (Fig. 3.1), especially in the upper reaches of the stream, but less than $10 \%$ of that mercury was the more toxic methylmercury (Fig. 3.2). Total mercury concentrations in striped shiner, a more omnivorous forage fish, were generally lower than those found in stonerollers at the three most upstream sites, but the two species had comparable concentrations downstream. In comparison to stonerollers, methylmercury comprised a much higher percentage (up to $60 \%$ ) of the total concentration.

The total mercury results in sunfish fillets are summarized in Fig. 3.3. There appears to be little difference in mean mercury concentrations in sunfish above and below the remediation sites (EFK 22.0 is located downstream of the NOAA site and EFK 13.8 is downstream of the Bruner site). Methylmercury was not measured in sunfish fillets because previous studies have shown that mercury in fish fillet is typically $95-100 \%$ methylmercury. In comparison to forage fish collected at the same site, total mercury concentrations in sunfish fillets are most similar to the total mercury levels in stonerollers. As previously mentioned, however, the methylmercury fraction in whole-body stonerollers is much lower.

Previous monitoring of sunfish in EFPC has shown that mercury concentrations in fillets commonly exceed $0.5 \mu \mathrm{g} / \mathrm{g}$ total mercury and are a potential concern to human health if eaten. The results of the whole-body versus fillet comparison summarized in Fig. 3.4 illustrate that approximately $100 \%$ of the total mercury in fillets consists of the most toxic methylmercury form. The average total mercury concentration in sunfish whole bodies $(n=12)$ was $0.95 \mu \mathrm{g} / \mathrm{g}$, almost identical to the average in sunfish fillets (Fig. 3.4). However, less than half of the total mercury concentration in sunfish whole bodies was methylmercury (average methylmercury $0.46 \mu \mathrm{g} / \mathrm{g}$ ).

\subsection{DISCUSSION}

Prior to remediation, there appeared to be little difference in mean total mercury concentrations in sunfish fillets and shiner whole bodies above and below the remediation sites. In contrast, the spatial pattern of mercury accumulation in stonerollers was more dichotomous, with mean mercury concentrations in the $1-1.6 \mu \mathrm{g} / \mathrm{g}$ range at the three most upstream sites and concentration in the $0.3-0.5 \mu \mathrm{g} / \mathrm{g}$ range at the two most downstream sites. The difference in accumulation patterns and mercury speciation among the three fish species is almost certainly due to the various differences in feeding regimes (herbivorous versus omnivorous, etc.). Future monitoring of these three species should provide, along with the baseline data, a measurable evaluation of any changes in mercury concentrations or speciation in fish. A finding of no change in fish mercury concentrations in these three species would provide strong evidence that the RAs were protective of the aquatic biota in EFPC.

The baseline studies for this task provide information useful to risk assessors and decision-makers who must evaluate the potential ecological risks associated with mercury bioaccumulation in LEFPC. Particularly useful are two components of this task: (1) the determination of the methylmercury fraction of each species and (2) the fillet versus whole-body mercury ratios in sunfish. Most bioaccumulation surveys measure total mercury in fish without determining the fraction that may be made up of the less toxic, inorganic mercury. Such surveys often only evaluate one species of fish. For this study, it was demonstrated that the two forage species collected from EFPC accumulated very different total mercury concentrations at some 


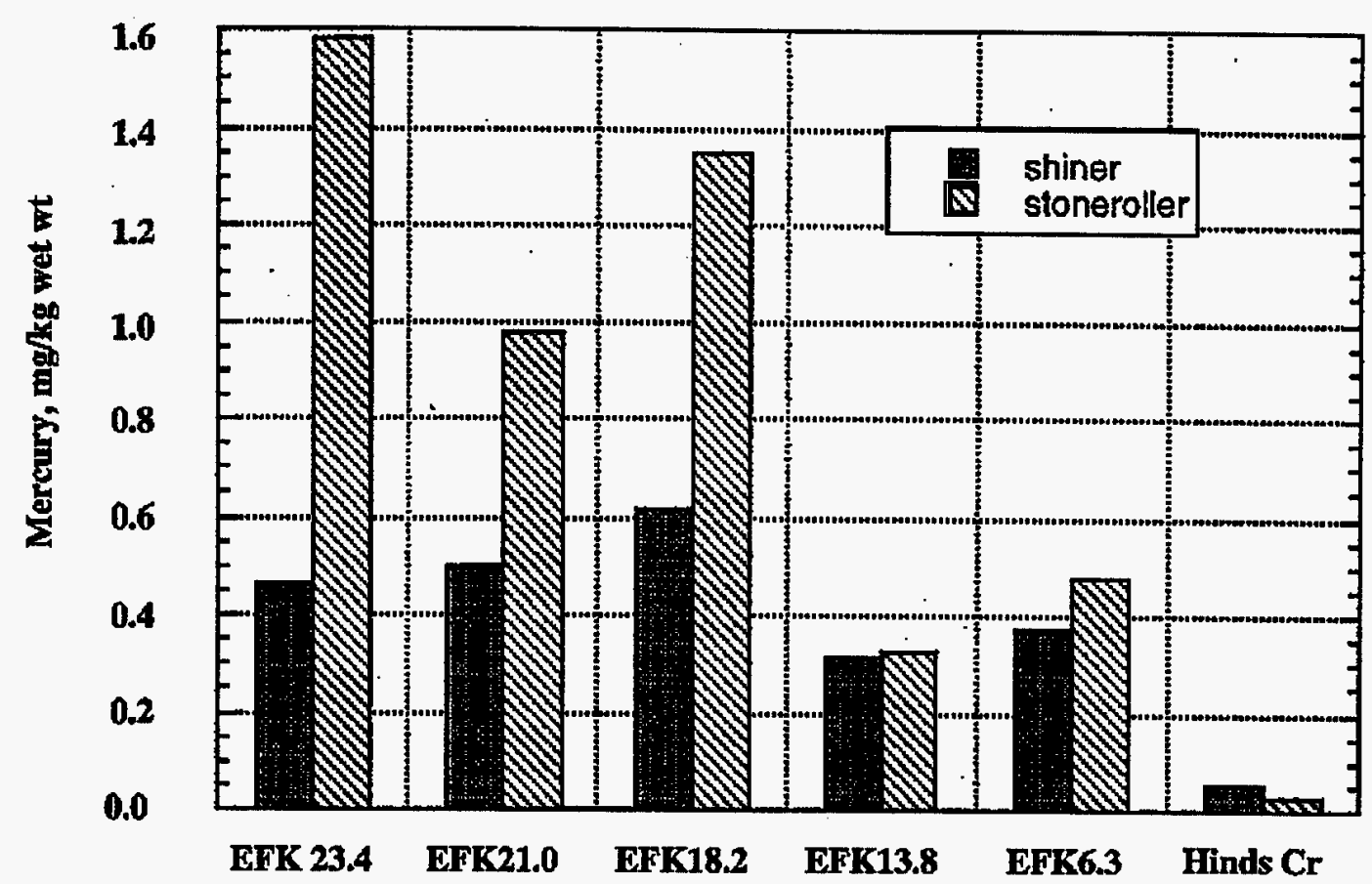

Fig. 3.1. Mean concentration of total mercury in composite samples $(n=3)$ of forage fish (stonerollers, Campostoma anomalum, and striped shiners, Luxilus chryscephalus), from sites in EFPC and Hinds Creek, fall and winter 1995/1996.

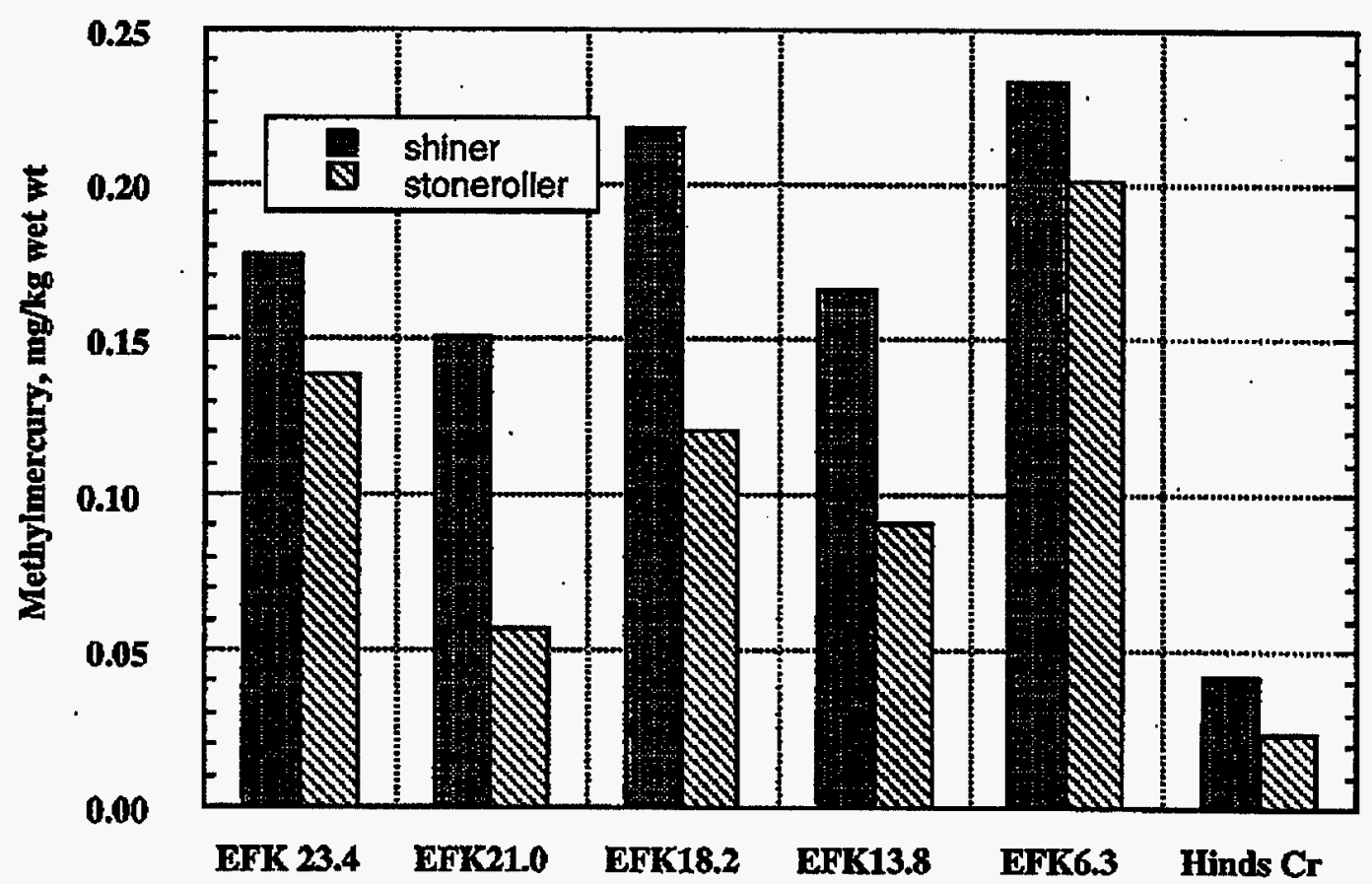

Fig. 3.2. Mean concentration of methylmercury in composite samples $(n=3)$ of forage fish (stonerollers, Campostoma anomalum, and striped shiners, Luxilus chryscephalus), from sites in EFPC and Hinds Creek, fall and winter 1995/1996. 


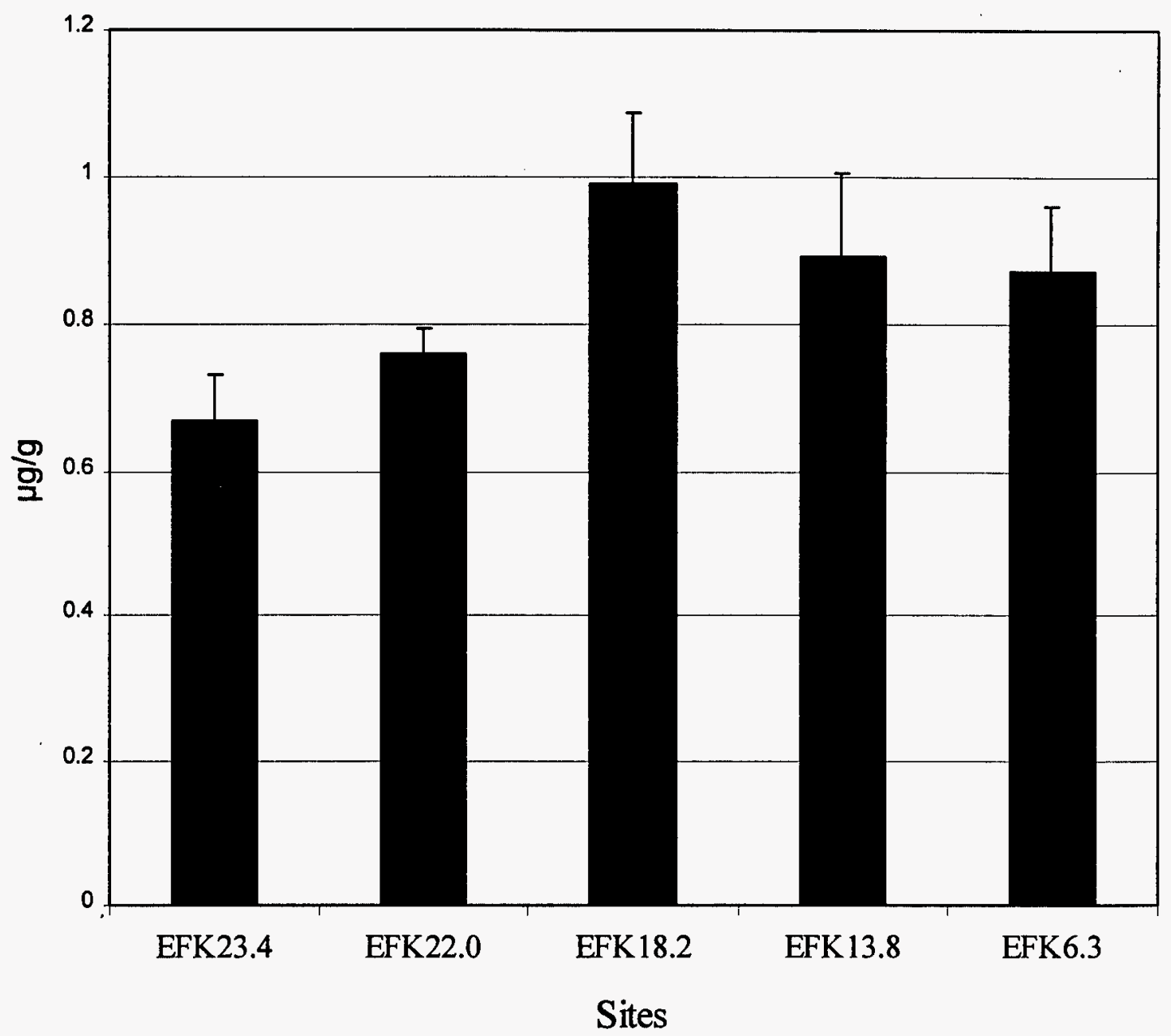

Fig. 3.3. Mean ( \pm SE) total mercury concentrations $(\mu \mathrm{g} / g$, wet $w t$.) in redbreast sunfish (Lepomis auritus) fillet samples collected from East Fork Poplar Creek, fall and winter 1995/1996 (N=8 at each site).

sites and reflected major differences in the fraction of total mercury composed of methylmercury. Concentrations of the much less toxic inorganic mercury in forage species were high enough (40-90\%) that evaluations of risk to piscivorous wildlife based on assumptions of $100 \%$ methylmercury in forage species are likely to be substantially overestimated.

The fillet versus whole-body study showed that sunfish fillet mercury concentrations routinely measured by BMAP throughout EFPC should be divided approximately in half to provide estimates of methylmercury concentrations in sunfish whole bodies. As was the case in forage fish, assumptions that the total mercury concentration in sunfish whole bodies is near $100 \%$ would be in error. Even with the high proportion of inorganic mercury in sunfish whole bodies, it is interesting to note that methylmercury concentrations in sunfish whole bodies were still higher than 
methylmercury concentrations in forage fish collected at the same sites. Therefore, the sunfish data in EFPC may provide an estimate of the near maximum ecological risk via fish ingestion. However, forage fish may be the preferred species to be used for ecological risk analysis because they may be more readily eaten by local piscivores such as kingfishers and mink (forage fish are of relatively small size, abundant, and common in shallow riffles).

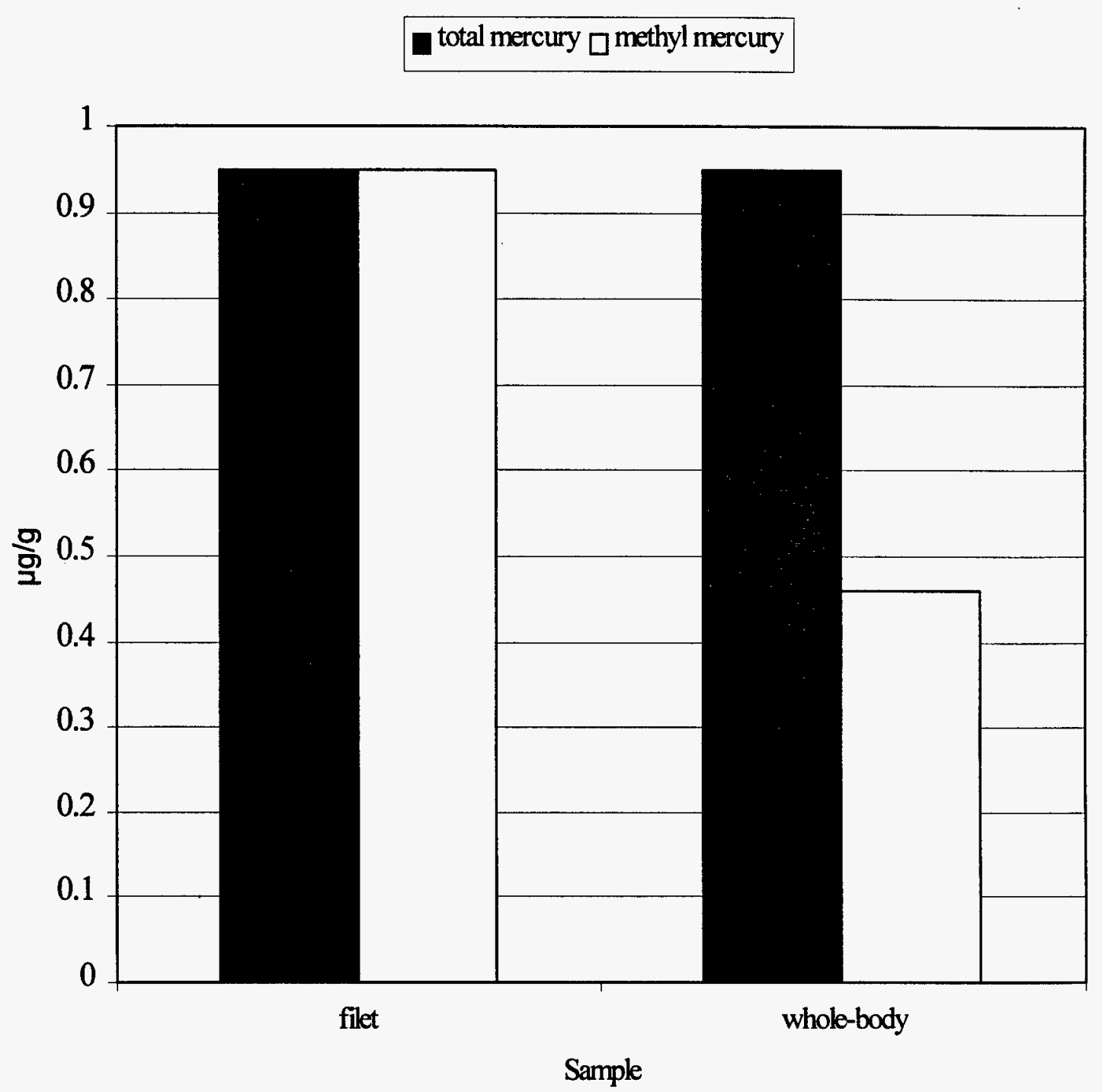

Fig. 3.4. Comparison of mean total mercury and methylmercury concentrations $(\mu \mathrm{g} / \mathrm{g}$, wet wt.) in redbreast sunfish (Lepomis auritus) fillet and whole-body samples collected from East Fork Poplar Creek, December 1996 (N=12). 


\section{SOIL AND ASSOCIATED BIOTA}

\subsection{INTRODUCTION}

As described in Chap. 1, the purpose of the terrestrial monitoring program is to determine if the remediation goal is protective of terrestrial biota. There are two protectiveness issues to be addressed. First, does remediation of soils with $>400 \mathrm{mg} / \mathrm{kg}$ total mercury effectively eliminate the risks they pose? Second, do unremediated soils with total mercury concentration approaching $400 \mathrm{mg} / \mathrm{kg}$ pose a significant risk to terrestrial biota?

To answer these two questions, a monitoring program was established to determine (1) the extent to which mercury in soil is accumulated by terrestrial biota and (2) whether this accumulation adversely affects the biota. European starlings (Sturnus vulgaris) were chosen as a representative of the midlevel predators that might be affected by soil concentrations of mercury. Starlings feed extensively on soil invertebrates, such as earthworms, that might be expected to accumulate mercury from the soil. Starlings are considered a pest species and are therefore not protected by federal or state wildlife regulations. They are cavity nesters, and the number of cavities available limits their reproduction. Thus, starlings will readily colonize any available cavity, provided there is suitable foraging habitat (i.e., open fields) nearby. During nesting season they can be expected to forage relatively close to their nests to provide the large quantity of food required by the nestlings.

Five sites were monitored during the nesting season of the preremediation year of 1996; three of these sites were again monitored during the nesting season of 1997. Two areas where mercury contamination was present but $<400 \mathrm{mg} / \mathrm{kg}$ (the Oak Ridge Country Club and the former Jackson Farm) were selected to determine the protectiveness of not remediating these sites. Two other sites where remediation was planned because concentrations of total mercury were $>400 \mathrm{mg} / \mathrm{kg}$ (the floodplain behind the NOAA buildings and the floodplain across from the former Bruner building) were chosen to determine if risks were acceptable after remediation. At all of the sites we attempted to place the nest boxes in the area where contamination had been measured, even though this meant that the boxes were not necessarily in the best starling habitat. A reference site, Freels Bend, was also selected to provide an uncontaminated location for comparison with the contaminated sites.

\subsection{MATERIALS AND METHODS}

The extent of bioaccumulation was determined by measuring total mercury and methylmercury in samples of soil, earthworms, and starling eggs and nestlings. Soil was collected using a stainless-steel spoon to scrape surface soil ( $\sim 1-2 \mathrm{~cm}$ deep) from an $\sim 1-\mathrm{m}^{2}$ area roughly in the center of each starling sample site. Soil samples were placed in a precleaned glass container provided by the analytical laboratory. After collection, soil samples were frozen until shipment to the analytical laboratory.

Earthworms were collected and depurated in accordance with SOP-1 of the BMAP Quality Assurance Plan (Ashwood 1996). This procedure involves adding an aqueous solution of mustard to an $\sim 1-\mathrm{m}^{2}$ area and collecting emerging earthworms with stainless-steel forceps. Earthworms were depurated (voided their intestines of soil) in warm water overnight, placed in a precleaned glass container provided by the analytical laboratory, and frozen until shipment. All earthworms from a particular site were composited into one sample from that site. 
Starling monitoring was conducted in accordance with procedures developed by Kendall et al. (1989) for field testing of pesticide effects. Ten nest boxes were placed at each site. Nest boxes were monitored periodically to determine the onset of egg laying, clutch size, number of eggs that hatched, number of nestlings that fledged, and weight of nestlings that lived to 16 days. Samples were collected of eggs and nestling and one dead adult. All eggs, nestlings, and the adult were treated as individual samples and were placed in aluminum foil and frozen until shipment to the analytical laboratory. Samples were analyzed for total mercury and methylmercury by Brooks Rand, Ltd., using aqueous-phase ethylation followed by cryogenic-gas chromatography with cold-vapor atomic fluorescence detection (Bloom 1989).

\subsection{RESULTS}

Total mercury and methylmercury in soils were lowest at the Freels Bend reference site, intermediate at the contaminated sites that were not scheduled to be remediated during the RA, and highest at the sites to be remediated (Table 4.1). Both total mercury and methylmercury in soils exhibited an increasing gradient with distance upstream along EFPC. Earthworms had lower mercury concentrations and higher methylmercury concentrations than the soil from which they were collected (Table 4.1). Except at Freels Bend (where all methylmercury values were low) and at terrestrial (site) near East Fork Poplar Creek (TNEFK) 22.6, starling eggs and nestlings had lower total mercury and higher methylmercury concentrations than the earthworms from the same locations.

In 1996, no starlings nested at the TNEFK 17.3 site (across from the former Bruner building), and only one starling pair nested at the TNEFK 22.6 site (behind the NOAA building). Both sites are wooded sites, not consistent with the open areas usually preferred by starlings. These two sites were undergoing remediation during 1997 , so no additional monitoring could be performed at these locations that year.

Predation losses had a significant effect on fledgling data at the TNEFK 10.0 site (near the Oak Ridge Country Club) in 1996 (Table 4.2) and at all three sites in 1997 (Table 4.3). In general, however, there was no apparent effect of site or year on any of the population parameters (clutch size, number hatched, or number fledged) or on nestling weight (two-way analysis of variance statistical procedure, $p>0.23$ for all variables and all effects). It should be noted that 1997 nestling data are insufficient anywhere but TNEFK 14.0 to test for a 1 -year effect or a site $X$-year interaction.

\subsection{DISCUSSION}

As expected, soil concentrations of total mercury and methylmercury track the location along EFPC, with those sites nearest the Y-12 Plant having the highest concentrations of both analytes. Earthworm concentrations mirror the soil results, and it is clear that earthworms are concentrating methylmercury (Table 4.1). This bioconcentration of methylmercury continues up the food chain from earthworms to starlings. At TNEFK 22.6, starling concentrations of methylmercury are lower than at other EFPC sites and lower even than earthworms from TNEFK 22.6. The most likely explanation for this lower concentration is that starlings were feeding on prey from areas outside the EFPC floodplain. This is consistent with the relatively poor (wooded) foraging habitat surrounding the site and the fact that only one starling pair constructed a nest at the site. 
Table 4.1. Total mercury (Hg) and methylmercury (MeHg) concentrations in soil, earthworms, and starlings from Lower East Fork Poplar Creek and an uncontaminated reference site ${ }^{a}$

\begin{tabular}{|c|c|c|c|c|c|c|c|c|c|c|c|}
\hline \multirow[b]{2}{*}{ Site } & \multirow[b]{2}{*}{ Common Name } & \multicolumn{2}{|c|}{ Soil } & \multicolumn{2}{|c|}{ Earthworms } & \multicolumn{2}{|c|}{ Eggs } & \multicolumn{2}{|c|}{ Nestling } & \multicolumn{2}{|c|}{ Adult } \\
\hline & & $\mathrm{Hg}$ & $\mathrm{MeHg}$ & $\mathrm{Hg}$ & $\mathrm{MeHg}$ & $\mathrm{Hg}$ & $\mathrm{MeHg}$ & $\mathrm{Hg}$ & $\mathrm{MeHg}$ & $\mathrm{Hg}$ & $\mathrm{MeHg}$ \\
\hline TNEFK 10.0 & Country Club & 54104 & 14 & 12580 & 177 & 630 & 385 & 500 & 403 & & \\
\hline TNEFK 14.0 & Jackson Farm & 71034 & 26 & 18487 & 144 & 434 & 240 & 494 & 335 & 1352 & 879 \\
\hline TNEFK 17.3 & Bruner Site & 99660 & 22 & 30078 & 585 & & & & & & \\
\hline TNEFK 22.6 & NOAA Site & 283665 & 78 & 81949 & 1544 & & & 194 & 140 & & \\
\hline
\end{tabular}

${ }^{a}$ All values are in ng/g; TFREELSBDI $=$ Terrestrial (site) near Freels bend (reference site), TNEFK = Terrestrial (site) near East Fork Poplar Creek kilometer 
Table 4.2. Starling population data collected from the Lower East Fork Poplar Creek floodplain and an uncontaminated reference site during $1996^{a}$

\begin{tabular}{|c|c|c|c|c|c|c|c|c|c|c|c|c|}
\hline \multicolumn{13}{|c|}{1996} \\
\hline \multirow[b]{2}{*}{ Site } & \multicolumn{3}{|c|}{ Clutch Size } & \multicolumn{3}{|c|}{ Eggs Hatched } & \multicolumn{3}{|c|}{ Nestlings Fledged } & \multicolumn{3}{|c|}{ Nestling Weight (g) } \\
\hline & Mean & $\begin{array}{c}\text { Std. } \\
\text { Dev. }\end{array}$ & $\mathbf{n}$ & Mean & $\begin{array}{l}\text { Std. } \\
\text { Dev. }\end{array}$ & $\mathbf{n}$ & Mean & $\begin{array}{l}\text { Std. } \\
\text { Dev. }\end{array}$ & $\mathbf{n}$ & Mean & $\begin{array}{l}\text { Std. } \\
\text { Dev. }\end{array}$ & $\mathbf{n}$ \\
\hline TFREELSBD1 & 5.29 & 0.49 & 7 & 3.71 & 2.06 & 7 & 2.50 & 2.35 & 6 & 78.00 & 4.79 & 14 \\
\hline TNEFK 10.0 & 4.71 & 0.76 & 7 & 4.14 & 1.07 & 7 & & & & & & \\
\hline TNEFK 14.0 & 5.40 & 0.52 & 10 & 3.67 & 1.80 & 9 & 2.88 & 1.96 & 8 & 77.74 & 7.51 & 23 \\
\hline TNEFK 17.3 & & & & & & & & & & & & \\
\hline TNEFK 22.6 & 5.00 & & 1 & 5.00 & * & 1 & 5.00 & & 1 & 80.50 & 4.51 & 4 \\
\hline
\end{tabular}

${ }^{a}$ FREELSBDI $=$ Terrestrial (site) near Freels bend (reference site), TNEFK = Terrestrial (site) near East Fork Poplar Creek kilometer

Table 4.3. Starling population data collected from the Lower East Fork Poplar Creek and an uncontaminated reference site during $1997^{\circ}$

\begin{tabular}{|c|c|c|c|c|c|c|c|c|c|c|c|c|}
\hline \multicolumn{13}{|c|}{1997} \\
\hline \multirow[b]{2}{*}{ Site } & \multicolumn{3}{|c|}{ Clutch Size } & \multicolumn{3}{|c|}{ Eggs Hatched } & \multicolumn{3}{|c|}{ Nestlings Fledged } & \multicolumn{3}{|c|}{ Nestling Weight (g) } \\
\hline & Mean & $\begin{array}{l}\text { Std. } \\
\text { Dev. }\end{array}$ & $\mathrm{n}$ & Mean & $\begin{array}{l}\text { Std. } \\
\text { Dev. }\end{array}$ & $\mathbf{n}$ & Mean & $\begin{array}{l}\text { Std. } \\
\text { Dev. }\end{array}$ & $\mathbf{n}$ & Mean & $\begin{array}{l}\text { Std. } \\
\text { Dev. }\end{array}$ & $\mathbf{n}$ \\
\hline TFREELSBD1 & 4.83 & 0.75 & 6 & 3.67 & 0.58 & 3 & & & & & & \\
\hline TNEFK 10.0 & 5.00 & 1.07 & 8 & 2.50 & 3.54 & 2 & & & & 87.20 & 3.03 & 5 \\
\hline TNEFK 14.0 & 5.18 & 0.87 & 11 & 4.30 & 0.82 & 10 & 3.88 & 1.13 & 8 & 81.17 & 4.61 & 30 \\
\hline
\end{tabular}

${ }^{a}$ FREELSBDI $=$ Terrestrial (site) near Freels bend (reference site), TNEFK = Terrestrial (site) near East Fork Poplar Creek kilometer 
Despite the substantially higher methylmercury concentrations in starlings from the EFPC sites as compared to Freels Bend, there is no evidence of a decline in any of the population parameters or nestling weight (Tables 4.2 and 4.3) with increasing methylmercury concentration. This is certainly true at the Country Club and Jackson Farm sites where there were data from multiple boxes. At the NOAA and Bruner sites, the data are too sparse to draw any firm conclusions, though the limited data from NOAA suggest the likelihood of little or no impact on population parameters or nestling weight.

Predation losses were especially devastating at the Country Club site in both years. Steps were taken after 1996 to reduce predation at all sites, including (1) moving the boxes at Jackson Farm away from the fence, (2) extending the aluminum flashing along the entire length of the support poles at all sites, and (3) using wooden bushings to extend the depth of the entry hole. Clearly, none of these steps were sufficient because predation in 1997 was more widespread than in 1996. Additional steps that might help in the future include increasing the height of the support poles, moving the Freels Bend boxes further from a nearby fence, and conducting extensive trapping for raccoons and other mammalian predators before and during the starling monitoring season.

Based on the starling population data, it appears that the level of contamination at the Country Club and Jackson Farm sites is not adversely affecting these bird populations even though they are clearly receiving methylmercury contamination. A similar conclusion cannot be drawn for the NOAA and Bruner sites because of insufficient data. However, the real test for these latter two sites is whether they pose a risk in their remediated condition. The lack of starling nest activity at these two sites during 1996 was due to the heavily wooded character of the sites. The postremediation cover at these sites is likely to be more conducive to starling monitoring at least for a few years. Therefore, we recommend that monitoring be conducted at the Bruner and NOAA sites after remediation is complete. Monitoring should also continue at the Freels Bend site to provide a reference for comparison with the contaminated sites. 


\section{WELL SURVEILLANCE ACTIVITY}

\subsection{INTRODUCTION}

A visual surveillance of the EFPC floodplain was conducted, as specified in the LEFPC Monitoring Plan, to provide information to DOE as to the presence of new groundwater wells in the LEFPC floodplain. At DOE's request, the state's well drilling report database was also obtained from the Division of Water Supply of the Tennessee Department of Environment and Conservation in Nashville. These activities were conducted to address concerns about the potential risks to human health if the shallow groundwater aquifer in the EFPC floodplain is used for drinking water.

\subsection{MATERIALS AND METHODS}

Privately owned land adjoining EFPC was visually inspected for the presence of wells on March 25, 1997. The area surveyed was adjacent to the stream and included the reach from approximately $\mathrm{km} 8$ (i.e., the point $8 \mathrm{~km}$ upstream of the stream mouth) to $\mathrm{km} 21$.

The policy on property access in the reach dictated how the actual survey was performed: inspection was by foot or vehicle on a public roadway, by foot on land with access agreements, or by walking the stream bed. The individuals conducting the survey were knowledgeable about the appearance of privately-owned wells. The presence or absence of wells on privately-owned land adjacent to the stream was documented on a field form. The form included information such as site/reach, parcel number, date, time surveyed, personnel, signatures, well presence and appearance, and a comments field.

\subsection{RESULTS}

Results of the survey were reported to the LEFPC project manager and the Environmental Management Program's Document Management Center (DMC) in correspondences dated June 13, 1997. Only one suspicious site was observed, where it appeared a well may have been dug in the past; a rusted, standing pipe with a lock was observed at this site, but current residential use seemed unlikely since buildings were not in the immediate vicinity.

\subsection{DISCUSSION}

Results of the survey were reported to the LEFPC project manager and the DMC in correspondences dated June 13, 1997. Original field forms were also submitted. An electronic disk from the Tennessee Department of Environment and Conservation was also submitted to the LEFPC project manager and the DMC. The disk contains a list of all documented drilling activities reported to the state in three quadrangles encompassing the EFPC floodplain. Based on this experience in conducting the visual survey of well usage, as specified in the LEFPC Monitoring Plan, we recommend the discontinuation of visual surveys and reliance on the state's well drilling report database for any future groundwater-usage surveillance activity in the LEFPC floodplain. 


\section{REFERENCES}

Ashwood, T. L. 1996. Biological Monitoring and Abatement Program Quality Assurance Plan, Bioaccumulation Monitoring-Terrestrial, ESQAP-96-0201, Rev. 0, Environmental Sciences Division, Oak Ridge Natl. Lab., Oak Ridge, Tenn.

Bloom, N. 1989. "Determination of picogram levels of methylmercury by aqueous phase ethylation followed by cryogenic gas chromatography with cold vapor atomic fluorescence detection," Canadian Journal of Fisheries and Aquatic Sciences, 46:113140.

EPA (U.S. Environmental Protection Agency) 1991. Methods for Determination of Metals in Environmental Samples, EPA-600/4-91-010, Environmental Monitoring Systems Laboratory, U.S. Environmental Protection Agency, Cincinnati, Ohio.

EPA 1994. Methods for Measuring the Toxicity and Bioaccumulation of Sediment Associated Contaminants with Freshwater Invertebrates, EPA 600/R-94/024, Office of Research and Development, U.S. Environmental Protection Agency, Duluth, Minn.

Greeley, M. S., Jr. 1996. Memorandum from M. S. Greeley, Jr., to M. C. Wiest. "Progress Report on the Oak Ridge Y-12 Plant Biological Monitoring and Abatement Program for East Fork Poplar Creek, Third Quarter 1996," Oak Ridge Natl. Lab., Oak Ridge, Tenn.

Hinzman, R. L. (ed.). 1993. Second Report on the Oak Ridge Y-12 Plant Biological Monitoring and Abatement Program for East Fork Poplar Creek, Y/TS-888, Oak Ridge Y-12 Plant, Oak Ridge, Tenn.

Hinzman, R. L. (ed.). 1996. Third Report on the Oak Ridge Y-12 Plant Biological Monitoring and Abatement Program for East Fork Poplar Creek, Draft Y/TS-889, Oak Ridge Y-12 Plant, Oak Ridge, Tenn.

Kendall, R. J., et al. 1989. The Use of Starling Nest Boxes for Field Reproductive Studies: Provisional Guidance Document and Technical Support Document, Environmental Research Laboratory, Office of Research and Development, U.S. Environmental Protection Agency, Corvallis, Oreg.

Kszos, L. A., et al. 1996. Environmental Sciences Division Toxicology Laboratory Quality Assurance Program Standard Operating Procedures, QAP-X-ES-002, Rev.1, Oak Ridge Natl. Lab., Oak Ridge, Tenn.

Lewis, P. A., et al. 1994. Short-Term Methods for Estimating the Chronic Toxicity of Effluents and Receiving Waters to Freshwater Organisms, 3rd ed., EPA/600/4-91/002, U.S. Environmental Protection Agency, Cincinnati, Ohio.

Loar, J. M. 1992. First Report on the Oak Ridge Y-12 Plant Biological Monitoring and Abatement Program for East Fork Poplar Creek, Y/TS-886, Oak Ridge Y-12 Plant, Oak Ridge, Tenn. 
LMES (Lockheed Martin Energy Systems, Inc.) 1995. Mercury Abatement Report for the U.S. Department of Energy Oak Ridge Y-12 Plant for Fiscal Year 1995, Y/ER-251, Oak Ridge Y-12 Plant, Oak Ridge, Tenn.

LMES 1996. Mercury Abatement Report for the U.S. Department of Energy Oak Ridge Y-12 Plant for Fiscal Year 1996, Oak Ridge, Tennessee, Y/ER-277, Oak Ridge Y-12 Plant, Oak Ridge, Tenn.

LMES 1997. Mercury Abatement Report for the U.S. Department of Energy Oak Ridge Y-12 Plant for Fiscal Year 1997, Oak Ridge, Tennessee, Y/ER-297, Oak Ridge Y-12 Plant, Oak Ridge, Tenn.

Peterson, M. J., and T. L. Phipps 1997. Biological Monitoring and Abatement Program Quality Assurance Plan, Bioaccumulation Monitoring-Aquatic, Standard Operating Procedures, QAP-X-90-ES-065, Rev. 1, Oak Ridge Natl. Lab., Oak Ridge, Tenn.

SAIC (Science Applications International Corporation) 1996. Baseline and Postremediation Monitoring Program Plan for the Lower East Fork Poplar Creek Remedial Action Project, Oak Ridge, Tennessee, Y/ER-262/R1, Oak Ridge Y-12 Plant, Oak Ridge, Tenn.

SAS Institute, Inc. 1985. SAS User's Guide: Statistics, Version 5 Edition, SAS Institute, Inc. Cary, N.C. 


\section{DISTRIBUTION}

1. T. L. Ashwood

2. M. S. Greeley

3. L. A. Kszos

4. T. J. McLaughlin

5. P. T. Owen

6. M. J. Peterson

7. L. B. Raulston

8. File-EMEF DMC-RC 


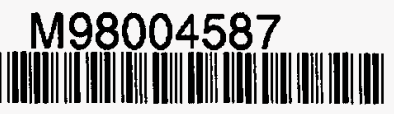

Report Number (14) $Y / E R-3 / 9$

Publ. Date (11)

199804

Sponsor Code (18) $\triangle O E / D P$ : DOE/EM,$X F$

UC Category (19) UC-702; UC-2000, DOE/ER 